\title{
Listeriosis Outbreak in Sheep Raised in Feedlots in the Southern Region of Rio Grande do Sul State, Brazil
}

\author{
Luiza Soares Ribeiro ${ }^{1}$, Haide Valeska Scheid ${ }^{1}$, Lucas dos Santos Marques ${ }^{2}$, Fabiano da Rosa Venancio ${ }_{\odot}{ }^{\text {, }}$ \\ Elisa Rocha da Silva ${ }^{2}$, Silvia Regina Leal Ladeira ${ }_{\odot}^{3}$ \& Ana Lucia Schild ${ }_{\odot}^{3}$
}

\begin{abstract}
Background: A listeriosis outbreak in a sheep fattening feedlot in the Southern Region of Rio Grande do Sul State, Brazil is described. This disease is caused by Listeria monocytogenes and represents a risk to public health since it affects not only ruminants but also humans. This agent is widely spread in the environment, such as in the soil and water. It is also found in decaying vegetable matter and the feces and fluids of domestic animals. The aim of this study was to describe a listeriosis outbreak in sheep raised in feedlots, its epidemiology, and to establish the importance of this disease in this type of sheep management system, evaluate the possible sources of infection, and suggest ways to control it.

Cases: Sheep were kept in a 2-sector shed, one with east solar orientation and the other with west solar orientation, the latter with free access to domestic birds. Sheep were fed silage and concentrate. Seven sheep were affected, 5 died and 2 recovered. Clinically, the sheep displayed loss of balance, excessive drooling, and tremors; one exhibited circling, head deviation, apathy, nystagmus, lateral recumbency, paddling, and labored breathing. At necropsy, macroscopic lesions were not found, and histologically several micro-abscesses and perivascular cuffs with lymphocytes, macrophages, and neutrophils were present in the brain stem. Listeria monocytogenes suspected colonies were observed in the microbiological culture, and the bacteria was identified by biochemical analysis. The immunohistochemistry test in brain stem sections was positive for the antibody BD Difco ${ }^{\mathrm{TM}}$ Listeria O Antiserum Poly Serotypes 1 and 4.

Discussion: A listeriosis outbreak in a feedlot sheep was confirmed through epidemiological findings, histological lesions, bacterial culture, and immunohistochemistry analysis. This infection is frequent in sheep fed silage of poor quality or other food with improper storage and lack of hygiene. In the present outbreak, the bacteria were isolated from silage. However, it is likely that domestic birds, which were raised in the same place and had free access to the west sector of the feedlot, were the initial source of infection, because the sheep from the opposite sector (east) did not get ill. The disease caused by environmental contamination or through contact with fluids and feces of ducks, chickens, cattle, and pigs has already been described in outbreaks that occurred in the central region of Rio Grande do Sul. Sheep aggregation in feedlot systems is also a favorable factor for the development of the bacteria and the occurrence of outbreaks because the accumulation of feces and urine cause humidity on the stalls. This allows outbreaks to occur in other seasons of the year, such as in the outbreak reported herein. The exchange of silage that served as food for sheep was another control measure, and new cases were not reported 8 months after these procedures were taken. In the outbreak studied, 2 sheep that exhibited clinical signs were treated with oxytetracycline and recovered. Some authors report that treatment for listeriosis is inefficient because neurological lesions are irreversible. Nonetheless, other studies have reported the recovery of some animals when they were treated with oxytetracycline or a combination of oxytetracycline and dexamethasone or ampicillin and gentamicin like in the outbreak described in this paper.
\end{abstract}

Keywords: Listeria monocytogenes, central nervous system, silage, feedlot, ovine. 
L.S. Ribeiro, H.V. Scheid, L.S. Marques, et al. 2022. Listeriosis Outbreak in Sheep Raised in Feedlots in the Southern Region

\section{INTRODUCTION}

Data from the Laboratório Regional de Diagnóstico (LRD) of the Universidade Federal de Pelotas (UFPel) show that from 2000 to 2019,8 cases of listeriosis in sheep were recorded. This disease is caused by Listeria monocytogenes and represents a risk to public health since it affects ruminants and humans $[8,11]$. This pathogenic bacterium can produce biofilm, which enables it to adhere to surfaces and survive for longer periods; therefore, it is capable of contaminating food [5] and is widely spread in the environment. It is also found in decaying vegetable matter [10] and the feces and fluids of domestic animals $[6,8]$.

In the southern region of Rio Grande do Sul state, listeriosis can occur in sheep raised on pasture, that in some cases, may be fed with silage or other feed [16]. The disease can cause encephalitis (nervous form), abortion, and systemic disorders in young animals [16]. The infection usually occurs when animals ingest low quality silage contaminated with feces and fluids of domestic and wild animals or if they are raised in an unhygienic environment $[4,13,15]$. Animals bearing the encephalic form display neurological signs, such as loss of balance, tremors, drooling, opisthotonus, and paddling. Normally, macroscopic lesions are absent, and histologic lesions are characterized by meningoencephalitis with the formation of micro-abscesses and perivascular cuffs in the brain stem $[3,15,16]$.

The aim of this study was to describe a listeriosis outbreak 7 sheep $(n=7)$ raised in feedlots, its epidemiology, and to establish the importance of this disease in this type of sheep management system, evaluate the possible sources of infection, and suggest ways to control it.

\section{CASES}

In a fattening feedlot of sheep, located in the municipality of São Lourenço do Sul, Rio Grande do Sul ( $31^{\circ} 22^{\prime} 24.6^{\prime \prime} \mathrm{S}, 51^{\circ} 58^{\prime} 16.5^{\prime \prime} \mathrm{W}$ ), the animals were housed in a shed with stalls for 35 animals each and fed with a mixture of corn silage and feed. The shed comprised east and west sectors. There was free movement of domestic birds in the west sector (Figure 1) that had access to water and food troughs; the opposite east sector was free from the birds.

During November 2020, 7 sheep exhibited neurological signs, 5 of that spontaneously died, and were necropsied. Two sheep that had moderate clinical

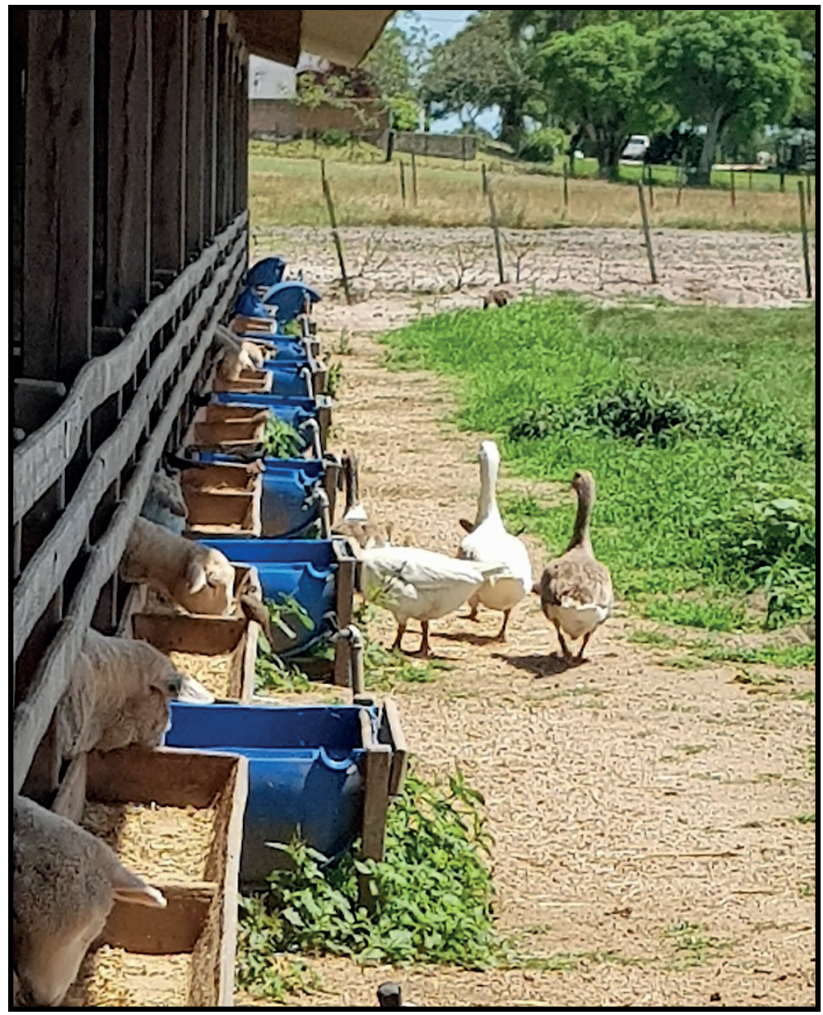

Figure 1. Listeriosis outbreak in sheep raised in a feedlot. Domestic birds with free access in a sector of the shed.

signs were treated with oxytetracycline (Oxitrat LA) ${ }^{1}$ for 3 days. Epidemiological data and clinical signs of the sheep were obtained with the owner.

During necropsies, fragments of the organs of the abdominal and thoracic cavities were collected and the entire central nervous system (CNS). They were fixed in $10 \%$ buffered formalin, routinely processed for histopathology, and stained with hematoxylin (ProCito $)^{2}$ and eosin (Vetec) ${ }^{3}$. The CNS fragments, water, feed, and bed of the sheep were sampled and sent to the laboratory of bacteriology of the LRD/UFPel to perform microbiological cultures. These samples were seeded on ovine blood agar $5 \%$, incubated in $37^{\circ} \mathrm{C}$ stove for $24-48 \mathrm{~h}$, in $10 \%$ concentration $\mathrm{CO}_{2}$. After stove incubation the suspected colonies were isolated, stained with Gram and submitted to biochemical analisis ${ }^{4}$ (catalasis, oxidasis, carbohidrates utilization, nitrate reduction, motility, indole production, hydrogen sulfide production, esculin hydrolysis, Voges-Proskauer and urease production). Because listeriosis was suspected to be the cause of death, after the analyses of histological slides, CNS sections were subjected to an immunohistochemistry test, according to previously established procedures [12], using the antibody BD 
L.S. Ribeiro, H.V. Scheid, L.S. Marques, et al. 2022. Listeriosis Outbreak in Sheep Raised in Feedlots in the Southern Region of Rio Grande do Sul State, Brazil. Acta Scientiae Veterinariae. 50(Suppl 1): 738.

Difco $^{\mathrm{TM}}$ Listeria $\mathrm{O}$ Antiserum Poly Serotypes 1 and $4^{5}$, at a $1: 100$ concentration ratio.

Out of an average of 878 sheep in the feedlot, 7 were affected by listeriosis. All of them were in the west sector of the shed. The first 2 animals that were ill and died were in the feedlot for 11 and 12 days, respectively, before the death. The third affected sheep was in the feedlot for 3 days and the other 2 for 10 and 30 days, respectively, before the death. The deaths occurred over a time of 8 days during November 2020. Three sheep that died were of the Polwarth breed, and the other 2 were Corriedale. The recovered sheep were Polwarth breed. The age of the all 7 affected sheep (5 males \& 2 females) ranged from 5-to-6-months. The epidemiological study of this outbreak revealed that the morbidity, mortality, and lethality rates were $0.79 \%$, $0.56 \%$, and $71.42 \%$, respectively.

Sheep displayed clinical signs including loss of balance (4/5), excessive drooling (3/5), and tremors (2/5); only 1 displayed circling, head deviation, apathy, nystagmus, lateral recumbency, paddling, and shortness of breath (Figure 2). Two sheep that had moderate clinical signs recovered after treatment with oxytetracycline. Also, the withdrawal of potential contamination sources (birds access to the shed and silage removal and change water, and bed) was done.

Macroscopic lesions were absent during necropsy. Histopathology revealed micro-abscesses, and perivascular cuffs with lymphocytes, macrophages, and neutrophils mainly in the brain stem region of CNS (thalamus, colliculus, pons, and medulla oblongata) [Figure 3].

Suspicious colonies of L. monocytogenes grew in the microbiological culture of the silage sample. The colonies were hemolytic, translucent, and small. On Gram staining, small gram-positive coccobacilli were observed, and the L. monocytogenes was identified through biochemical tests. Positive staining for the antibody BD Difco ${ }^{\mathrm{TM}}$ Listeria O Antiserum Poly Serotypes 1 and 4 in the immunohistochemistry analysis was observed in thalamus, colliculus pons, and medulla oblongata sections (Figure 4).

\section{DISCUSSION}

A listeriosis outbreak in feedlot sheep was confirmed through epidemiological findings, histological lesions, bacterial culture, and immunohistochemistry analysis. This infection is frequent in sheep fed silage of poor quality or other food with improper storage and



Figure 2. Listeriosis outbreak in sheep raised in a feedlot. Affected sheep showing lateral recumbency, opisthotonus, and paddling.

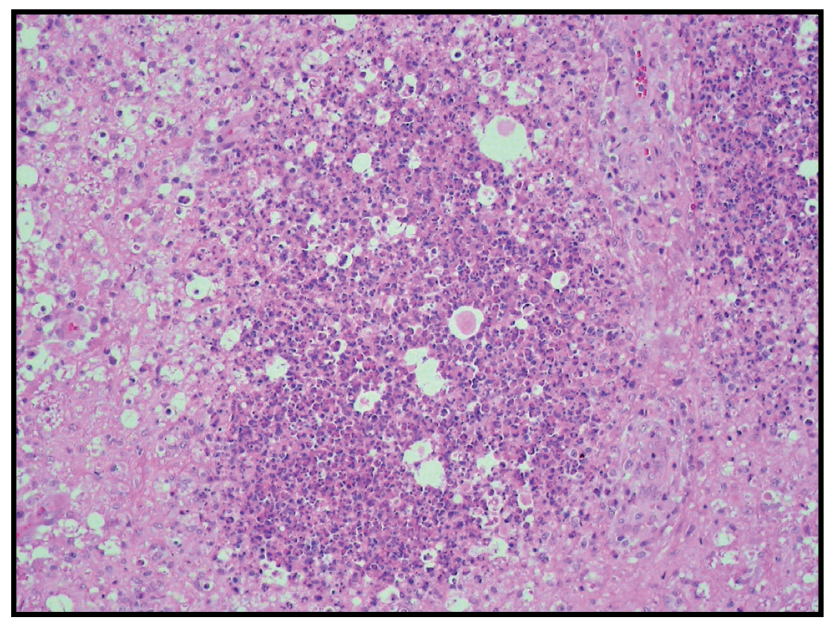

Figure 3. Listeriosis outbreak in sheep raised in a feedlot. In the medulla oblongata there are focal abscesses and around the neuropil is edematous and rarefied with swollen axons (spheroids) [HE; 200x].

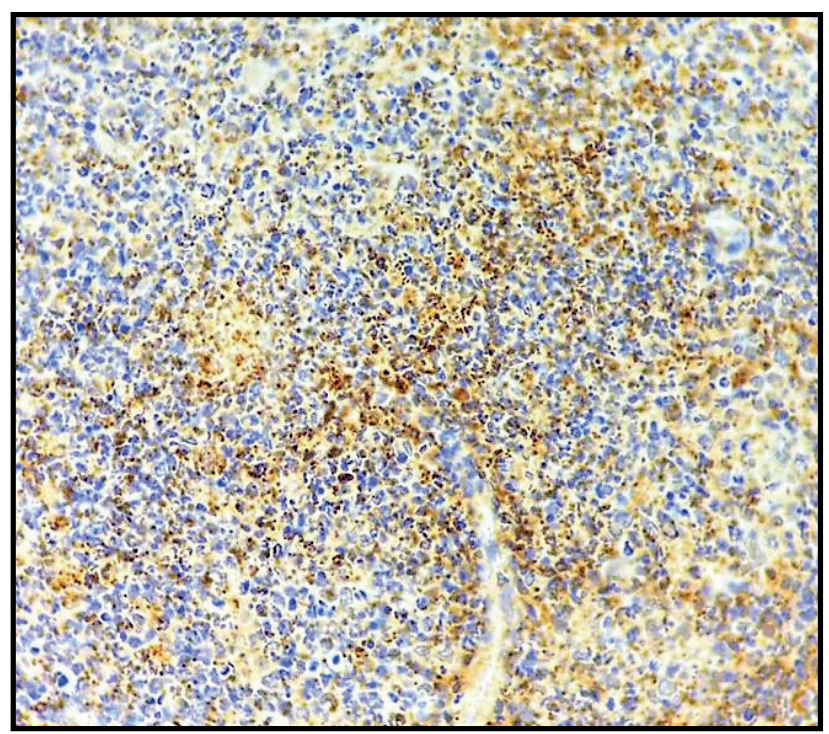

Figure 4. Listeriosis outbreak in sheep raised in a feedlot. Section of medulla oblongata and pons with cell positive in immunohistochemical staining using antibody Listeria O Antiserum Poly Serotypes 1 and 4 [200x]. 
lack of hygiene $[2,4,13]$. However, in the Rio Grande do Sul state, the disease is constantly observed in grazing sheep $[15,16]$ and, in some cases, even when they are not fed in troughs. In the present outbreak, the bacteria were isolated from silage. However, it is likely that domestic birds, which were raised in the same place and had free access to the west sector of the feedlot, were the initial source of infection, because the sheep from the opposite sector (east) did not get ill. The disease caused by environmental contamination or through contact with fluids and feces of ducks, chickens, cattle, and pigs has already been described in outbreaks that occurred in the central region of Rio Grande do Sul [15].

The listeriosis outbreak described in this study occurred in November. It has been mentioned that both in Brazil and in other countries, the disease mainly occurs in the winter and early spring [18]. However, the outbreaks diagnosed in the southern region of Rio Grande do Sul may occur during any season of the year, with no specific predominant season. During the winter, the weather is favorable for bacterial growth due to the capacity of their growth at low temperatures $\left(4^{\circ} \mathrm{C}\right)$, while other pathogens are inhibited by the excess of cold [9]. On the other hand, since Listeria spp. can grow at temperatures of up to $44^{\circ} \mathrm{C}$, it is evident that the disease can occur at any time of the year.

Sheep aggregation in feedlot systems is also a favorable factor for the development of the bacteria and the occurrence of outbreaks [18] because the accumulation of feces and urine cause humidity on the stalls. This allows outbreaks to occur in other seasons of the year, such as in the outbreak reported herein. It has been shown that hygiene measures and the preventing access to birds and other species in feedlot stalls are important measures to prevent listeriosis outbreaks, as feces and fluids from birds are sources of contamination by Listeria sp. [15]. The exchange of silage that served as food for sheep was another control measure, and new cases were not reported eight months after these procedures were taken. The age of the animals is a risk factor for infection. It has been reported that the disease generally affects adults $[15,18]$ and rarely affects lambs [19]. Between 2000 and 2019, 8 listeriosis cases or outbreaks were diagnosed in the southern region of Rio Grande do Sul in sheep and goat [17]. All affected sheep more than 1-year-old [17]. On the other hand, young animals can be frequently affected when they are losing and changing their teeth, which leads to lesions in the gums that the bacteria can penetrate [20]. In the present report, the age of the sheep ranged from 5 to 6 months. This suggests that the disease depends on more the environmental conditions than on the age of the animals. In sheep of up to 6-month-old, it was observed that nervous manifestations of listeriosis are more pronounced than in adult animals [20], and the lethality rate was significantly higher when compared to that in sheep older than 6 months [9].

In the outbreak studied, 2 sheep that exhibited clinical signs were treated with oxytetracycline and recovered. Some authors report that treatment for listeriosis is inefficient, because neurological lesions are irreversible $[14,18]$. Nonetheless, other studies have reported the recovery of some animals when they were treated with oxytetracycline [1] or a combination of oxytetracycline and dexamethasone [7] or ampicillin and gentamicin [1] like in the outbreak described in this paper.

It was concluded that listeriosis can be an important cause of mortality among feedlot sheep, and the accessibility of feedlots to domestic and wild birds should be considered as a possible contamination source.

\section{MANUFACTURERS}

${ }^{1}$ Vallée S.A. Produtos Veterinários. Montes Claros, MG, Brazil. ${ }^{2}$ Progau- Produtos para Laboratórios Ltda. Recife, PE, Brazil. ${ }^{3}$ Sigma Aldrich Brasil Ltda. Duque de Caxias, RJ, Brazil. ${ }^{4}$ Laboratório de Bacteriologia do Laboratório Regional de Diagnóstico (LRD), Faculdade de Veterinária - UFPel. Capão do Leão, RS, Brazil.

${ }^{5}$ Becton, Dixon and Company. Sparks, MD, USA.

Acknowledgements. The authors are grateful to Conselho Nacional de Desenvolvimento Científico e Tecnológico (CNPq), and Coordenação de Aperfeiçoamento de Pessoal de Nível Superior (CAPES) (finance code 001) for scientific, financial support and student's scholarship.

Declaration of interest. The authors report no conflicts of interest. The authors alone are responsible for the content and writing of the paper.

\section{REFERENCES}

1 Braun U., Stehle C. \& Ehrensperger F. 2002. Clinical findings and treatment of listeriosis in 67 sheep and goats. Veterinary Record. 150(2): 38-42.

2 Brugére-Picoux J. 2008. Ovine listeriosis. Small Ruminant Research. 76(1-2): 12-20. 
3 Câmara A.C.L., Olinda R.G., Batista J.S., Feijó F.M.C. \& Almeida R.D. 2014. Listeriose em ovinos associada ao consumo de silagem no Rio Grande do Norte. Revista Brasileira de Ciência Veterinária. 21(1): 19-22.

4 Driehuis F. 2013. Silage and the safety and quality of dairy foods: a review. Agricultural and Food Science. 22(1): 16-34.

5 Gandra T.K.V., Volcan D., Kroning I.S., Marini N., de Oliveira A.C., Bastos C.P. \& Silva W.P. 2019. Expression levels of the agr locus and prfA gene during biofilm formation by Listeria monocytogenes on stainless steel and polystyrene during 8 to $48 \mathrm{~h}$ of incubation 10 to $37^{\circ} \mathrm{C}$. International Journal of Food Microbiology. 300: 1-7. DOI: 10.1016/j. ijfoodmicro.2019.03.021.

6 George L.W. 2002. Listeriosis. In: Smith B.P. (Ed). Large Animal Internal Medicine. 3rd edn. St. Louis: Mosby Elselvier, pp.946-949.

7 Green L.E. \& Morgan K.L. 1994. Descriptive epidemiology of listerial meningoencephalitis in housed lambs. Preventive Veterinary Medicine. 18(2): 79-87.

8 Hofer E. \& Reis C.M.F.D. 2005. Espécies e sorovares de Listeria isolados de animais doentes e portadores no Brasil. Pesquisa Veterinária Brasileira. 25: 79-83.

9 Kumar H., Singh B.B., Bal M.S., Kaur K., Singh R., Sidhu P.K. \& Sandhu K.S. 2007. Pathological and epidemiological investigations into listerial encephalitis in sheep. Small Ruminant Research. 71(1-3): 293-297.

10 Linke K., Rückerl I., Brugger K., Karpiskova R., Walland J., Muri-Klinger S., Tichy A., Wagner M. \& Stessl B. 2014. Reservoirs of Listeria species in three environmental ecosystems. Applied and Environmental Microbiology. 80(18): 5583-5592. Disponível em: <http://aem.asm.org/content/80/18/5583.full>.

11 Oevermann A., Zurbriggen A. \& Vandevelde M. 2010. Rhombencephalitis caused by Listeria monocytogenes in humans and ruminants: a zoonosis on the rise? Interdisciplinary Perspectives on Infectious Diseases. DOI: $10.1155 / 2010 / 632513$

12 Ramos-Vara J.A. \& Beissenherz M.E. 2000. Optimization of immunohistochemical methods using two different antigen retrieval methods on formalin-fixed, paraffin-embedded tissues: experience with 63 markers. Journal of Veterinary Diagnostic Investigation. 12(4): 307-311.

13 Ribeiro L.A.O., Rodrigues N.C., Fallavena L.C.B., Oliveira S.J. \& Brito M.A. 2006. Listeriose em rebanho de ovinos leiteiros na região serrana do Rio Grande do Sul: relato de caso. Arquivo Brasileiro de Medicina Veterinária e Zootecnia. 58(3): 316-319.

14 Rissi D.R., Rech R.R., Barros R.R., Kommers G.D., Langohr I.M., Pierezan F. \& Barros C.S.L. 2006. Forma nervosa de listeriose em caprinos. Pesquisa Veterinária Brasileira. 26(1): 14-20.

15 Rissi D.R., Kommers G.D., Marcolongo-Pereira C., Schild A.L. \& Barros C.S.L. 2010. Meningoencefalite por Listeria monocytogenes em ovinos. Pesquisa Veterinária Brasileira. 30(1): 51-56.

16 Schild A.L. 2001. Listeriose. In: Riet-Correa F., Schild A.L., Mendez M.D.C. \& Lemos R.A.A. (Eds). Doenças de Ruminantes e Equídeos. 2.ed. São Paulo: Varela Livraria, pp.288-291.

17 Schild A.L., Marques L.S., Silva E.R., Scheid H.V., Ribeiro L.S. \& Venancio F.R. 2020. Doenças diagnosticadas pelo Laboratório Regional de Diagnóstico no ano 2019. In: Ladeira S.R.L., Ruas J.L., Soares M.P. \& Schild A.L. (Eds). Boletim do Laboratório Regional de Diagnóstico n 42. Pelotas: Editora e Gráfica Universitária, pp.9-20.

18 Spindola C.Z. 2017. Listeriose em ovinos e caprinos no estado de Santa Catarina: epidemiologia, clínica e diagnóstico. 53f. Lages, SC. Dissertação (Mestrado em Ciência Animal) - Programa de Pós-Graduação em Ciência Animal do Centro de Ciências Agroveterinárias, da Universidade do Estado de Santa Catarina.

19 Wardrope D.D. \& MacLeod N.S. 1983. Outbreak of listeria meningoencephalitis in young lambs. The Veterinary Record. 113(10): 213-214.

20 Younis E.E., El-Sawalhy A.A., Soumaya E.A. \& El-Beskawy M.A.A. 2010. Epidemiological studies on Listeriosis in sheep. Journal of Veterinary Medical Research. 20(1): 141-148. 